\title{
SEISMIC RISK ASSESSMENT IN THE ATTICA BASIN
}

\author{
Farangitakis G.P. ${ }^{1}$, Brentas O.G. ${ }^{2}$, Andreadakis E. ${ }^{1}$ and Lekkas E. ${ }^{1}$ \\ ${ }^{1}$ National and Kapodistrian University of Athens, Department of Geology, 15478, Athens, Greece, \\ pfarangit@geol.uoa.gr,eandreadk@geol.uoa.gr,elekkas@geol.uoa.gr \\ ${ }^{2}$ BNP Paribas, Bât. Balzac, 140-142 Boulevard Macdonald, 75019, Paris, France, \\ orestis.brentas@bnpparibas.com
}

\begin{abstract}
This paper aims to determine the exposure-based earthquake risk posed in the Attica Basin, Greece using a GIS based methodology. The hazard level is based on grouped geological formations according to the New Ground Anti-Earthquake Regulation of Greece and the structural setting of the area. Vulnerability is calculated using two different methodologies. The first one uses a deterministic approach by attributing population values to each building block divided by the acreage of each municipality and the second one uses a probabilistic approach by using centroids based on a building block level and then creating their kernel density. Both of these approaches are combined with land use maps to create the final vulnerability layers. Risk is calculated in two ways, using the product and a weighted overlay of the hazard and vulnerability layers. In the Risk maps, proof of concept comes from overlaying the damages from the earthquakes of 1981 and 1999 that affected Attica Basin. Moreover, both the maps show high Risk probability in the area of the east part of the Attica Basin but without significant damages from past earthquakes. This suggests that the Kifisos Fault Zone might act as a seismic barrier depending of the location of the epicentre.

Keywords: Athens earthquake, seismic hazard, vulnerability.
\end{abstract}

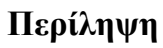

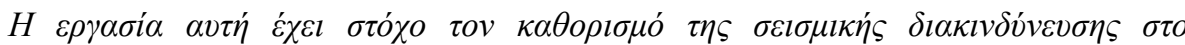

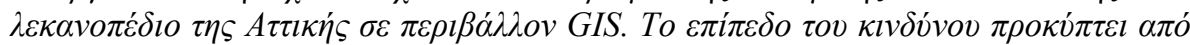

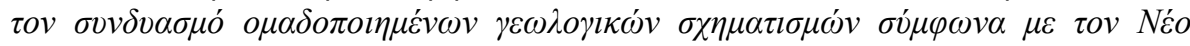

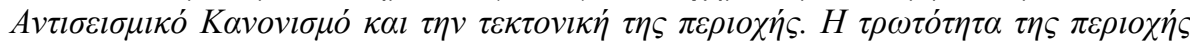

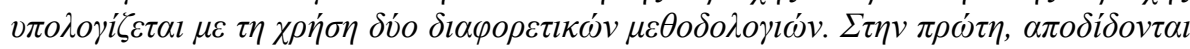

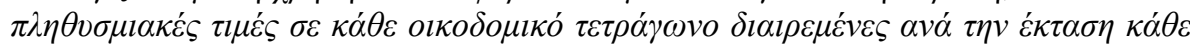

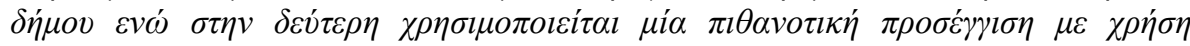

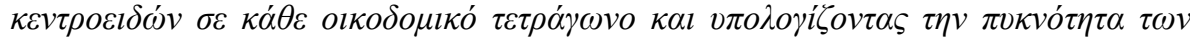

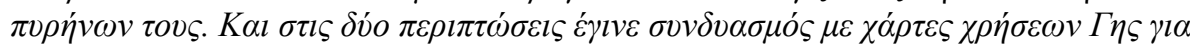

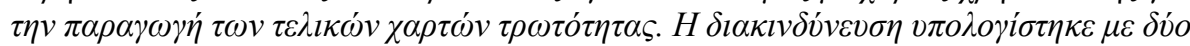

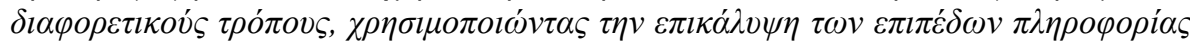

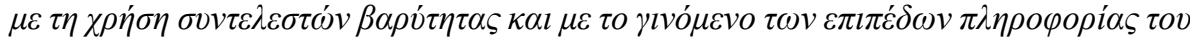

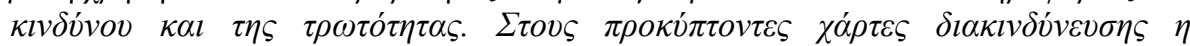

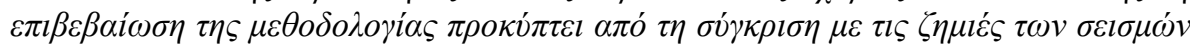

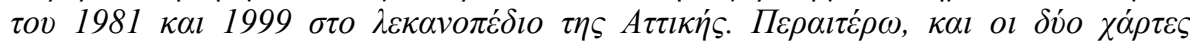

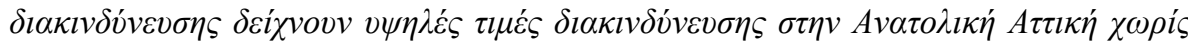

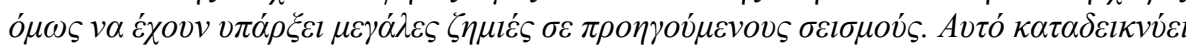




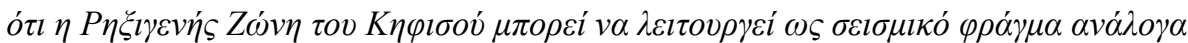

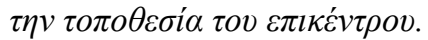

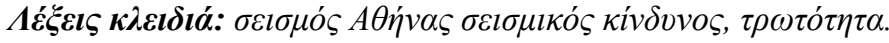

\section{Introduction}

The aim of this paper is to produce a seismic risk map for the Attica basin, Greece. The Attica basin is the most densely populated area of Greece, being the location of the capital city Athens which houses more than 5 million people. It has been hit by numerous earthquakes in the historical years with the most recent ones with significant human and financial losses being the seismic events of 1981 $(\mathrm{ML}=6.9 \mathrm{R})$ from the Corinth Gulf and $1999(\mathrm{ML}=5.9 \mathrm{R})$ from Parnitha Mountain. No previous work has been done in the field of seismic risk assessment for the Attica basin and since there is a number of possible earthquake producing prone zones in a relative vicinity, a need for a risk map is dire.

In general, seismic risk assessment began when Richter (1959), created a seismic zoning map of the United States based on a combination of a modified Mercalli intensity scale and the geology of the area. Using an intensity scale for calculating risk is subjectifying the final product, thus Algermissen et al. (1975) created a probabilistic map for maximum ground acceleration establishing a technique used until today. During the 1980s with the development of Geographical Information Systems (GIS) it became much easier to spatially distribute hazard and vulnerability elements to create risk maps. However, ground acceleration maps are still used as risk maps today as they are the key factor in urban areas and are easily quantifiable (Alexander, 1993). On the same principle Richter (1959), used, Papanikolaou (2011), developed a study in the Apennines using the ESI (2007), intensity scale. The main premise of this methodology is that the duration of maximum ground movement is more important than the numerical maximum of that movement, as this can be instantaneous. Using empirical syn-seismic slip rates, length of fracture and magnitude measurements along with relationships between magnitude and intensity, a very high resolution seismic hazard map can be produced. There is a number of ready-to-use software packages available for seismic risk assessment. One such tool is HAZUS (HAZards United States) developed by FEMA (Federal Emergency Management Agency). Its development began in 1997 and has been updated numerous times since. This software implements algorithms that calculate financial losses, human losses along with other impact on the population. It also can create scenarios regarding secondary consequences of the earthquakes (city fires, debris accumulation etc.) (FEMA, 2004). This specific methodology is target oriented and customized to areas of the US making it less transferable and applicable outside the US. A European variation of the HAZUS software is SELENA (Seismic Loss EstimatioN using a logic tree Approach) developed by Molina and Lindholm (2006) in a seismic risk assessment of Oslo (Molina and Lindholm, 2005). SELENA is based on MATlab software, demanding specialized users. Despite that, SELENA has the advantage of producing scenario-based risk maps (TomaDanila et al., 2015). A methodology based on the use of GIS environments, a variation of which was implemented in this work, is lastly presented here. The main difference between this methodology and the aforementioned is that the latter is far more customizable and versatile, as the layers of input information can be adjusted to the user's requirements, data availability and desired outcome. Such methodologies have been applied in various cities around the world such as Barcelona (Lantada $e t$ al., 2003), Brussels (Petermans et al., 2006), Thessaloniki (Pitilakis et al., 2006), Grenoble (Gueguen et al., 2007), Chania (Sarris et al., 2010) and Tabriz (Karimzadeh et al., 2014). Justification for this selection will be provided in the Materials and Methods chapter.

\section{Materials and Methods}

The produced risk map was based on the premise that Risk= Hazard*Vulnerability. The selected methodology for this paper was the one used by Sarris et al. (2010), as it covered most aspects and produced the most accurate result using the data available. It should be noted that this formula does not necessarily represent an algebraic multiplication, any more than an algebraic combination 
depending on the nature and the number of layers of information on the used parameters. The elements each methodology uses can be seen in the following table (Table 1).

Table 1 - Seismic Risk Assesment techniques.

\begin{tabular}{|c|c|c|c|c|c|c|}
\hline $\begin{array}{r}\text { Seismic Risk As } \\
\text { n }\end{array}$ & $\begin{array}{l}\text { ssessment Mappi } \\
\text { g }\end{array}$ & \begin{tabular}{|} 
Algermissen \\
et al., 1975 \\
\end{tabular} & $\begin{array}{c}\text { Papanikolaou, } 2 \\
\text { 011 } \\
\end{array}$ & HAZUS & SELENA & $\begin{array}{c}\text { Sarris et a } \\
l ., 2010 \\
\end{array}$ \\
\hline $\begin{array}{c}\text { Seismic Event } \\
\text { (Hazard) }\end{array}$ & $\begin{array}{c}\text { Ground Accelera } \\
\text { tion }\end{array}$ & & & & $\mathrm{v}$ & $\mathrm{v}$ \\
\hline & Seismic Velocity & $\mathrm{v}$ & & & $\mathrm{v}$ & $\mathrm{v}$ \\
\hline & Seismicity & & $\mathrm{v}$ & & & $\mathrm{v}$ \\
\hline & Geology & & & $\mathrm{v}$ & $\mathrm{v}$ & $\mathrm{v}$ \\
\hline & Tectonics & & $\mathrm{V}$ & $\mathrm{v}$ & & $\mathrm{v}$ \\
\hline & $\begin{array}{c}\text { Seismic Source } \\
\text { Analysis }\end{array}$ & & $\mathrm{v}$ & $\mathrm{v}$ & & \\
\hline $\begin{array}{c}\text { Urban Environ } \\
\text { ment (Vulnerab } \\
\text { ility) }\end{array}$ & $\begin{array}{c}\text { Population - Urb } \\
\text { an Planning - Lif } \\
\text { elines }\end{array}$ & & & $\mathrm{v}$ & $\mathrm{v}$ & $\mathrm{v}$ \\
\hline & Building Type & & & $\mathrm{v}$ & $\mathrm{v}$ & $\mathrm{v}$ \\
\hline & Building Value & & & $\mathrm{v}$ & $\mathrm{v}$ & \\
\hline Final Product & Intensity & & $\mathrm{v}$ & & & \\
\hline & $\begin{array}{c}\text { Ground Accelera } \\
\text { tion }\end{array}$ & $\mathrm{v}$ & & & & \\
\hline & Possible damage & & & $\mathrm{v}$ & $\mathrm{v}$ & \\
\hline & Risk & & & & & $\mathrm{v}$ \\
\hline Resulting Map & & Hazard & Hazard & Risk & Risk & Risk \\
\hline
\end{tabular}

\subsection{Hazard}

The creation of a seismic hazard map was based on the use of 3 layers of information; geology, tectonics and slopes (calculated on a raster map created by the contours of the area using ArcGIS 10. The geology of the area was obtained from Papanikolaou et al. (2001), and each geological formation was classified accordingly to the corresponding NGASR (New Ground Anti-Seismic Regulation) category (as seen in Table 2). The distribution of these formations can be seen in Figure 1 (left).

Each geological formation was assigned a weighing factor, depending on the NGASR classification (Table 3).

On the same principle, faults and thrusts were assigned weighting factors and buffer zones depending on whether they are considered active (Papanikolaou et al., 2001) (Table 4).

Finally, weighting factors were assigned to different ranges of slope, depending on the results of the ArcGIS slope tool and they were classified into 6 classes using the Natural Breaks (Jenks, 1967) method (Table 5).

These three levels of information (geology, tectonics, slope) were assigned weighting factors, after creating raster layers from polygon themes, using the Reclassify tool of ArcGIS 10 (Table 6). The raster layers were combined using the Weighted Overlay tool to create the final Hazard map (Figure 1 right). 
Table 2 - Geological formations in the Attica basin and NGASR classification.

\begin{tabular}{|c|c|c|}
\hline $\begin{array}{l}\text { NGASR } \\
\text { Category }\end{array}$ & Geological Formations & Description \\
\hline A & $\begin{array}{l}\text { Thin bedded Upper Cretaceous } \\
\text { limestone and shales } \\
\text { Miocene travertines } \\
\text { Mesozoic Marbles } \\
\text { Mesozoic Schists } \\
\text { Pelagic Clastic limestones } \\
\text { Phyllites } \\
\text { Triassic-Jurassic pelagic limestones } \\
\text { Triassic crystallic limestones } \\
\text { Triassic dolomites and marbles } \\
\text { Upper Cretaceous Neritic } \\
\text { Limestones } \\
\text { Upper Miocene Limestones } \\
\text { Upper Palaeozoic- } \\
\text { Lower Triassic clastic formations }\end{array}$ & $\begin{array}{l}\text { Rocky or semi-rocky formations extending in signi } \\
\text { ficant extent and depth, without heavy weathering. } \\
\text { Layers of thick grainy material with low rate of sil } \\
\text { t-muddy admixture with thickness lower than } 70,0 \\
0 \mathrm{~m} \text {. } \\
\text { Layers of very tough pre-compressed mud with thi } \\
\text { ckness lower than } 70,00 \mathrm{~m} \text {. }\end{array}$ \\
\hline B & $\begin{array}{l}\text { Pleiocene sea formations } \\
\text { Dilluvial deposits } \\
\text { Ophiolites } \\
\text { Upper Miocene sea formations } \\
\text { Upper Miocene terrestrial } \\
\text { formations } \\
\text { Upper Pliocene lake formations } \\
\end{array}$ & $\begin{array}{l}\text { Highly weathered rocky formations or formations that, } \\
\text { by mechanical aspect, can be assimilated to rocky. } \\
\text { Layers of grainy material of medium density and t } \\
\text { hickness greater than } 5,00 \mathrm{~m} \text { or of great density wi } \\
\text { th thickness greater than } 70,00 \mathrm{~m} \text {. } \\
\text { Layers of tough pre-compressed mud with thickne } \\
\text { ss greater than } 70,00 \mathrm{~m} \text {. }\end{array}$ \\
\hline$\Gamma$ & $\begin{array}{l}\text { Alluvial deposits } \\
\text { Pleiocene terrestrial formations } \\
\text { Talus cones and fans } \\
\text { Talus cones }\end{array}$ & $\begin{array}{l}\text { Layers of grainy material with low relative density } \\
\text { with thickness greater than } 5,00 \text { m or with mediu } \\
\text { m density with thickness greater than } 70,00 \mathrm{~m} \text {. } \\
\text { Silty-muddy soils of low durability in thickness gr } \\
\text { eater than } 5,00 \mathrm{~m} \text {. }\end{array}$ \\
\hline$\Delta$ & & $\begin{array}{l}\text { Ground with soft muds of high indicator formation } \\
(\mathrm{I} \rho>50) \text { with total thickness greater than } 10,00 \mathrm{~m}\end{array}$ \\
\hline $\mathrm{X}$ & $\begin{array}{l}\text { Human Deposits } \\
\text { Coastal Deposits } \\
\text { Shoal Deposits } \\
\text { River Deposits } \\
\text { Estuaries } \\
\text { Fans }\end{array}$ & $\begin{array}{l}\text { Loose fine-grained sand-muddy soils under the water } \\
\text { horizon that are possible to be liquefied (unless the s } \\
\text { pecial study do not find such a danger or a reclamatio } \\
n \text { of the territorial capacities takes place) } \\
\text { soils that are close to obvious tectonic breaches. } \\
\text { Steep inclines that are covered by products of loos } \\
\text { e side detritus } \\
\text { Loose grainy or soft mud-argillaceous soils as long } \\
\text { as it has been proved that are dangerous from the as } \\
\text { pect of dynamic condensation or loss of strength } \\
\text { Recent loose banking ups (rubble), organic soils } \\
\text { of C category with dangerously great incline. }\end{array}$ \\
\hline
\end{tabular}

Table 3 - NGASR classes and weighting factors.

\begin{tabular}{|l|l|}
\hline NGAER class & Weighting factor \\
\hline $\mathrm{A}$ & 2 \\
\hline $\mathrm{B}$ & 4 \\
\hline$\Gamma$ & 6 \\
\hline $\mathrm{X}$ & 10 \\
\hline
\end{tabular}


Table 4 - Structural elements of the Attica basin with buffer zones and weighting factors.

\begin{tabular}{|l|l|l|}
\hline Status & Buffer Zone & Weighting factor \\
\hline Inactive faults & 50 & 5 \\
\hline Potentially active faults & 50 & 5 \\
\hline Active faults & 100 & 10 \\
\hline Thrust & 50 & 5 \\
\hline
\end{tabular}

Table 5 - Slopes in Attica basin and attributed weighting factors.

\begin{tabular}{|l|l|}
\hline Slope in Degrees & Weighting factor \\
\hline $0-6$ & 1 \\
\hline $6-15$ & 2 \\
\hline $16-30$ & 5 \\
\hline $34-45$ & 8 \\
\hline $46-60$ & 9 \\
\hline$>61$ & 10 \\
\hline
\end{tabular}

Table 6 - Final weighting factors for the Hazard map.

\begin{tabular}{|l|l|}
\hline Raster Layers & Weighting factor \\
\hline Geology & $50 \%$ \\
\hline Faults and Thrusts & $40 \%$ \\
\hline Slope & $10 \%$ \\
\hline
\end{tabular}

\subsection{Vulnerability}

The creation of a vulnerability map was based on the exposed elements using in this case population and land use. The population data came from the 2001 census conducted by the Hellenic Statistic Agency, while the land use data came from the Corine Programme of the European Environmental Agency. Building block data were provided by Attiko Metro S.A. These datasets were combined using two different methodologies.

\subsubsection{Population per building block}

This methodology involved calculation of the total area of the building blocks per municipality within the area of interest. The number of residents in the municipality (as provided by the census data of 2001 which was available at the time) was then divided by the number of blocks; producing the population density per square meter. Then the population density was multiplied by the area of each individual building block in the municipality and the population per block was calculated depending on its size. The outcome, which is an approximate estimation limited by tha accuracy of the data, is presented in the left map of Figure 2.

Depending on the population of the building block, a weighting factor was assigned (Table 7).

Respectively, the data from Corine 2000 were given a weighting factor (Table 8 and Figure 2 right).

The two maps were combined using the Weighted Overlay tool of ArcGIS with $60 \%$ of the total weight assigned to land use and $40 \%$ to population density. The difference in weight is a matter of precaution against bad calculations regarding population density. The results can be seen in the map of Figure 3 (left).

\subsubsection{Probabilistic Density of Population}

This methodology made use of the per block population calculated before, in order to create Centroids and calculate the population throughout the study area and not just per municipality. For this reason the Centroids created were introduced to the "Kernel Density" tool of ArcGIS in order to calculate the Probabilistic Density per square kilometre. Kernel density estimation is a non- 
parametric way to estimate the probability density function of a random variable. Kernel density estimation is a fundamental data smoothing problem where inferences about the population are made, based on a finite data sample. Moreover, it could in fact be more accurate, taking in mind that, depending on the time of the day, population is not necessarily contained in the buildings, but disperesed in the whole area instead. 10 Natural Breaks were selected and were given weighting factors from 1 to 10 when rasterized.

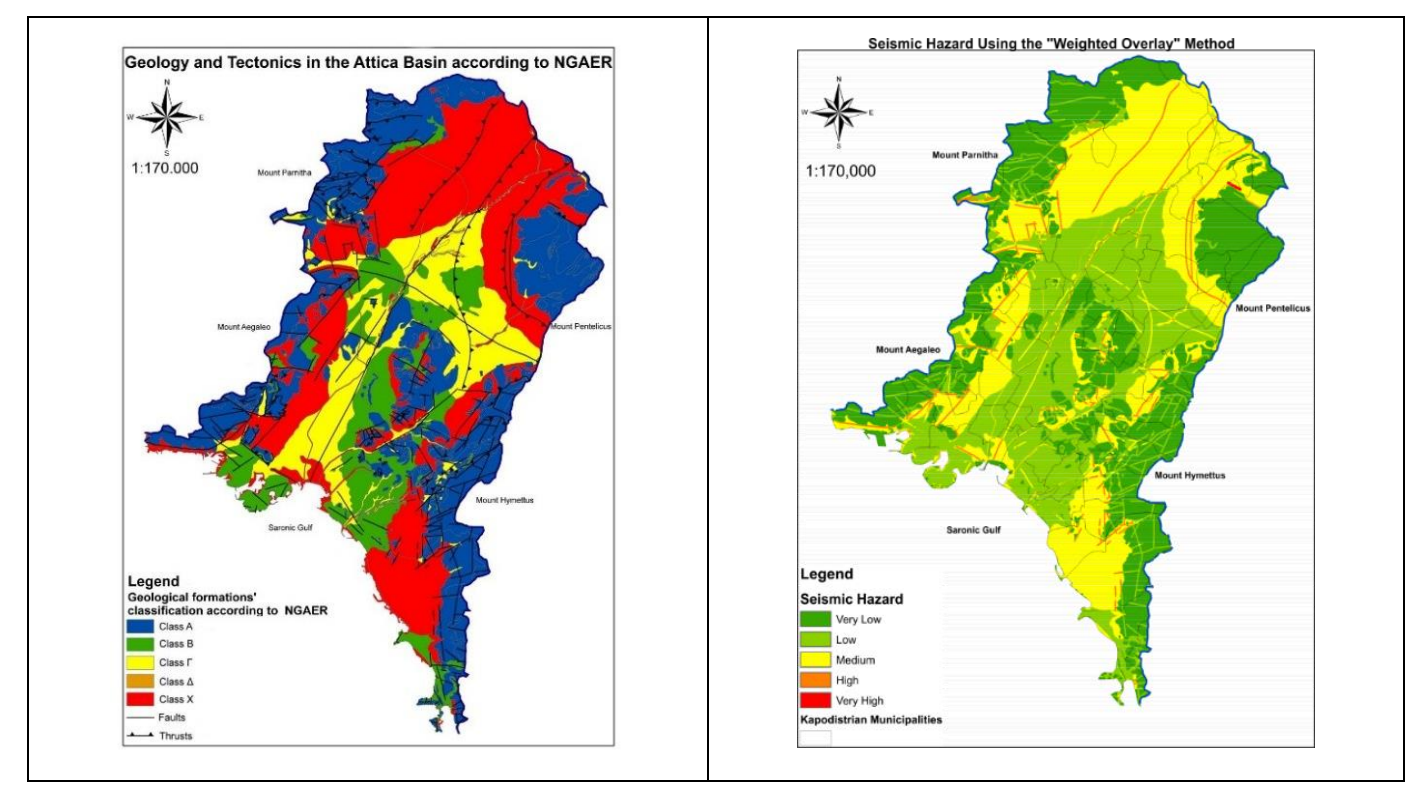

Figure 1 - Geological formations classification according to NGASR (left) and Seismic Hazard Map (right).

Table 7 - Building block population and weighting factors.

\begin{tabular}{|l|l|l|l|}
\hline $\begin{array}{l}\text { Number of people per Weighting } \\
\text { building block }\end{array}$ & $\begin{array}{l}\text { Number of people per } \\
\text { factor }\end{array}$ & Weighting factor \\
\hline $0-18$ & 1 & $153-217$ & 6 \\
\hline $18-43$ & 2 & $217-314$ & 7 \\
\hline $43-73$ & 3 & $314-485$ & 8 \\
\hline $73-108$ & 4 & $485-925$ & 9 \\
\hline $108-153$ & 5 & $925-1411$ & 10 \\
\hline
\end{tabular}

Again the resulting map was combined with the land use using the "Weighted Overlay" tool; with $60 \%$ of the weight assigned to land use and $40 \%$ to population data. The results are shown in the map of Figure 3 (right).

\subsection{Risk}

To create the Seismic Risk Map for the study area 2 different methodologies were used. These were:

Raster Calculator: Hazard and Vulnerability layers were combined using the "Raster Calculator" tool of ArcGIS based on the formula of Risk (Risk=Hazard*Vulnerability) in its strict sense.

Weighted Overlay: Using the "Weighted Overlay" tool of ArcGIS the Hazard and Vulnerability layers were combined using weighting factors. The weighting factors were $50 \%-50 \%$. 


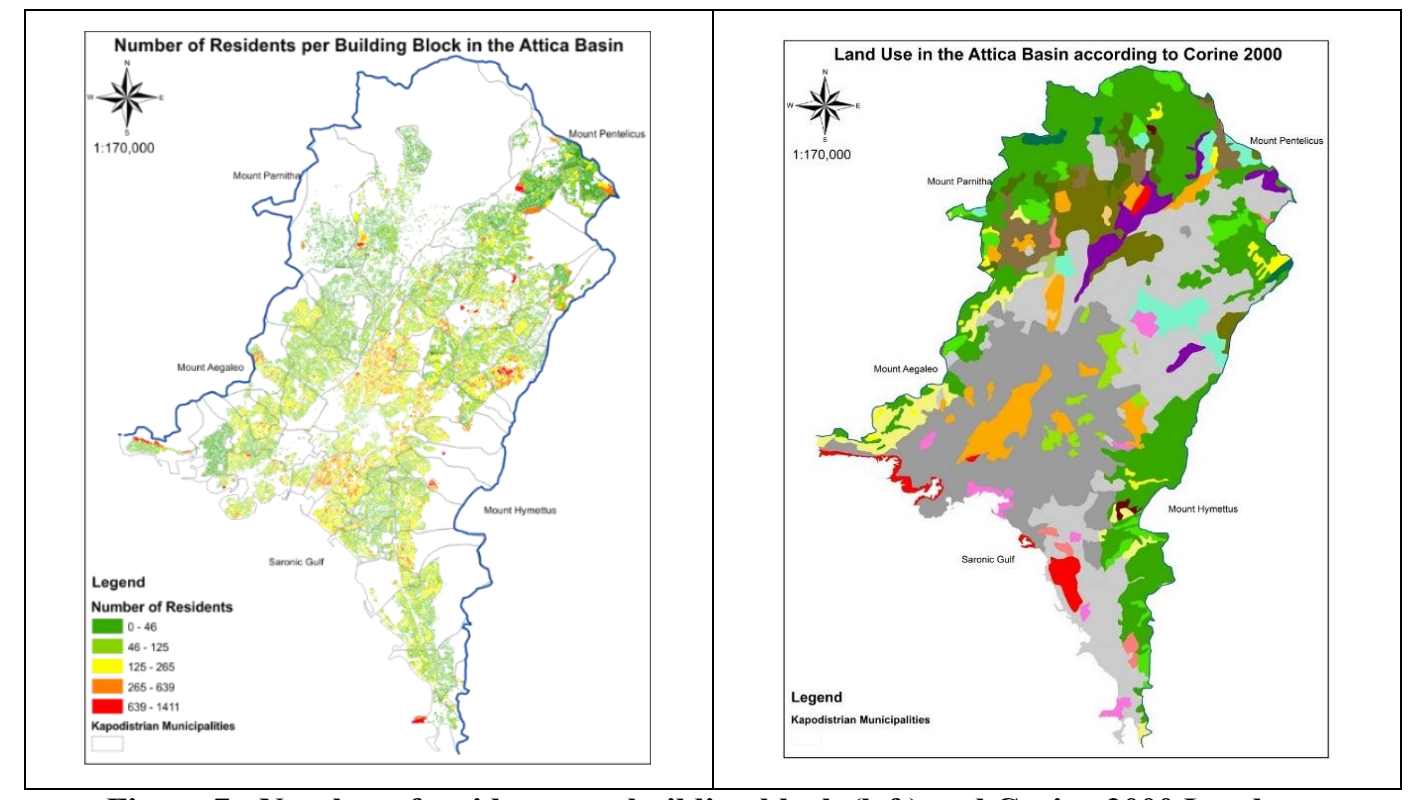

Figure 7 - Number of residents per building block (left) and Corine 2000 Land use classification (right).

Table 8 - Corine2000 classes, color coding and weighting factors.

\begin{tabular}{|c|c|c|c|}
\hline $\begin{array}{l}\text { Corine2000 } \\
\text { code }\end{array}$ & $\begin{array}{l}\text { Color } \\
\text { Coding }\end{array}$ & Description & $\begin{array}{l}\text { Weighting } \\
\text { Factor }\end{array}$ \\
\hline 111 & & Continuous Urban Fabric & 8 \\
\hline 112 & & Discontinuous Urban Fabric & 8 \\
\hline 121 & & Industrial, Commercial and Public Units & 9 \\
\hline $122,123,124$ & & $\begin{array}{l}\text { Road and Rail Networks and associated Land, } \\
\text { Port Areas, Airports }\end{array}$ & 10 \\
\hline 131 & & Mineral Extraction sites & 5 \\
\hline 133 & & Construction sites & 8 \\
\hline 141 & & Green Urban areas & 4 \\
\hline 142 & & Sport and Leisure facilities & 6 \\
\hline 211 & & Non-irrigated arable land & 5 \\
\hline 221 & & Vineyards & 4 \\
\hline 222 & & Fruit Trees and berries plantations & 4 \\
\hline 223 & & Olive groves & 4 \\
\hline 242 & & Complex Cultivation patterns & 4 \\
\hline 243 & & $\begin{array}{l}\text { Land principally occupied by agriculture, with } \\
\text { significant areas of natural vegetation. }\end{array}$ & 3 \\
\hline 244 & & Agro-forestry areas & 3 \\
\hline 311 & & Broad-leaved forest & 1 \\
\hline 312 & & Coniferous forest & 1 \\
\hline 313 & & Mixed forest & 1 \\
\hline 321 & & Natural grasslands & 2 \\
\hline 322 & & Moors and heathland & 2 \\
\hline 323 & & Sclerophyllous vegetation & 2 \\
\hline $0 \mathrm{pt}$ & & Transitional woodland-scrub & 2 \\
\hline 333 & & Sparsely vegetated areas & 2 \\
\hline 334 & & Incinerated areas & 5 \\
\hline
\end{tabular}




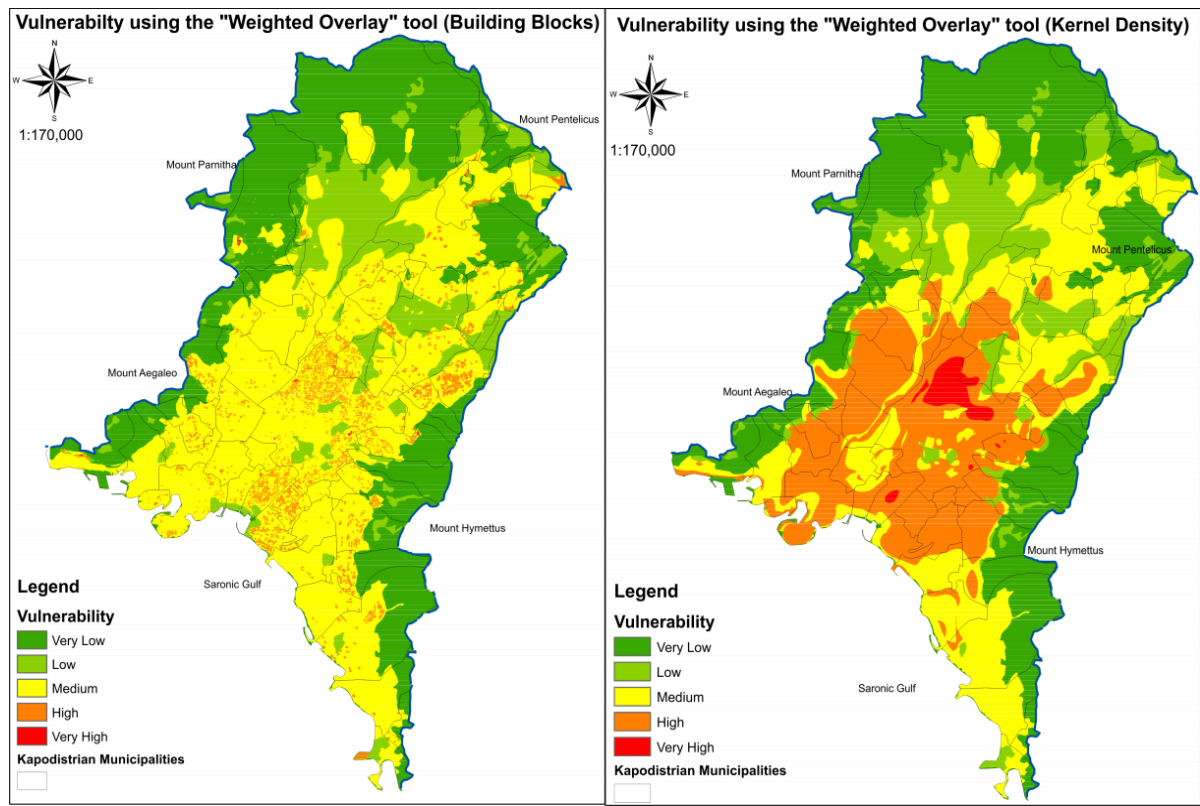

Figure 3 - Weighted overlay vulnerability map using the building block (left) and Kernel Density (right) population distribution.

In each case, the Hazard map was combined two times with each vulnerability layer producing four final Risk maps which will be presented in the Results chapter.

\section{Results and Discussion}

As said before, risk was calculated using two different methodologies. The first two maps (Figure 4), concern the Raster Calculator tool, where a maximum Risk value of 0.8-1 is possible (where the Very High Risk category would apply). It is clear that no place on the map can acquire a risk value this high according to the used vulnerability and hazard data.

On the first map, the Aegaleo and Hymettus foothills, along with the coastal areas of P. Faliron and Pireas and the urban centre of Athens, have the highest risk value. Meanwhile, on the second map the same areas still maintain a high risk value but with a relatively smaller extent. This differentiation between the two maps, can be attributed to the fact that on the second map the population density is distributed in a level of building blocks while first map presents the population divided by Kernel density. This results in the second map having a more sharpened end result, affected by more factors such as fault presence, geology, morphology and population density. Still, on both the maps, the High and Very High Risk value does not appear.

The last two maps (Figure 5) have been constructed with the "weighted overlay" method, using the weighting factors mentioned previously. A first observation is that the weighted overlay result, results in higher values. This can be attributed to the fact that this method sharpens the differences between areas and amplifies those with increased Hazard and Vulnerability factors. Similarly to the raster calculator methodology, the first map has been produced using the Kernel density of the population, while the second one has been developed based on a building block-based population distribution. Accordingly, on the first map, the risk is higher on the foothills of Aegaleo and Hymettus Mts, on the Kifissos estuaries and the Penteli fault zone. It is remarkable that these areas now can be classified as High Risk contradicting the Raster Calculator method that classified them as Medium Risk. In this map, the Medium Risk category is attributed to the whole populated region of Attiki with lower values on the less densely populated areas. Moreover, the areas closer to the faults, are again sharpened towards higher risk values, due to the "weighted overlay" method 
increasing the Risk where the Hazard or Vulnerability factors are increased. Analyzing the last weighted overlay map, it is clear that the Medium and High Risk categories are even more extended throughout the map. This applies mostly because the Vulnerability layer concerning the population density is once again provided on a building block level. Thus, the High Risk category extends in more areas, such as the Glyfada fan, the whole Kifissos area, the Pikrodafni stream, the Thrakomakedones fan, the Pentelikon Mt foothills and the hilly areas of the urban center of Athens. This can be attributed to the fact that the Hazard layer contribution increases exponentially when the Vulnerability layer is analyzed on a building block level.

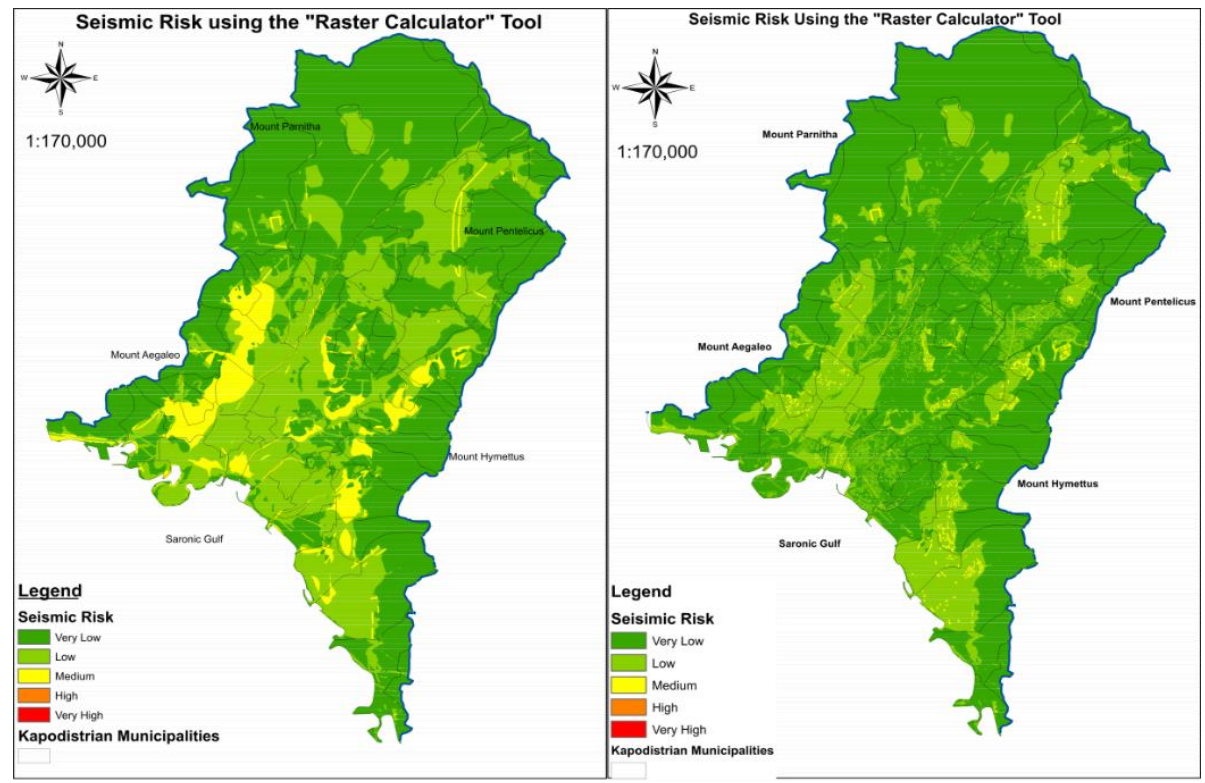

Figure 4 - "Raster Calculator" risk maps using: the Kernel density based vulnerability map (left) and the building block based vulnerability map (right).

In both cases, classification of risk was applied using natural breaks in order to avoid polarising the data. Risk maps can vary, depending on the data layers that are inserted on the Vulnerability and Hazard layers. This is up to the user and the availability of valid and up to date data. In this paper the population data used were from the 2001 since the 2011 census data were not available. Also real estate values were not included. Thus, when Vulnerability is concerned, along with the population and land use data, an array of additional information can be added such as real estate values, lifelines, specific scenarios depending on the time the event happens with the final result varying each time. Despite all the different possible inputs, the ultimate reliability of a Risk map, can only be evaluated through comparison with damages from past or future seismic events. This paper's final risk maps show a significant overall match of the medium and high risk areas with the Athens 1999 earthquake damage distribution in the western part of the city (Figure 6). The only area there is notable difference (as far as extent of high risk is concerned) is the Adames (Kifissia) region, and this is due to the fact the topographic slope has been attributed a relatively low gravity factor, and the geological data available were limited. One major issue that occurs when observing the results, is that in both the recent major seismic events that affected Athens $(1981,1999)$ no severe damage was observed east of Kifissos river. This can be attributed to the fact that the Kifissos Fault Zone, acts as an 'insulator' against earthquakes occurring in the west of the basin, defracting (or even reflecting) the distribution of the seismic energy. Moreover, the Artemida and Kallidromon earthquakes (June and August of 2013 respectively) justify the 'insulator' theory. Testimonies of Attica residents across social networks and media, reported that both these incidents were more perceptible in the northern and southern areas of the basin rather than the centre and the west (if at all). Thus, it is worth making a special note on the Glyfada fan which has been highlighted with a 
high risk value in the last map, since according to Papanikolaou et al. (2001) it has similar mechanical characteristics to the Thrakomakedones fan making it equally susceptible (or possibly even more since the Glyfada fan is more densely populated and has higher real estate values) to potential damages in a seismic event located east of the river.

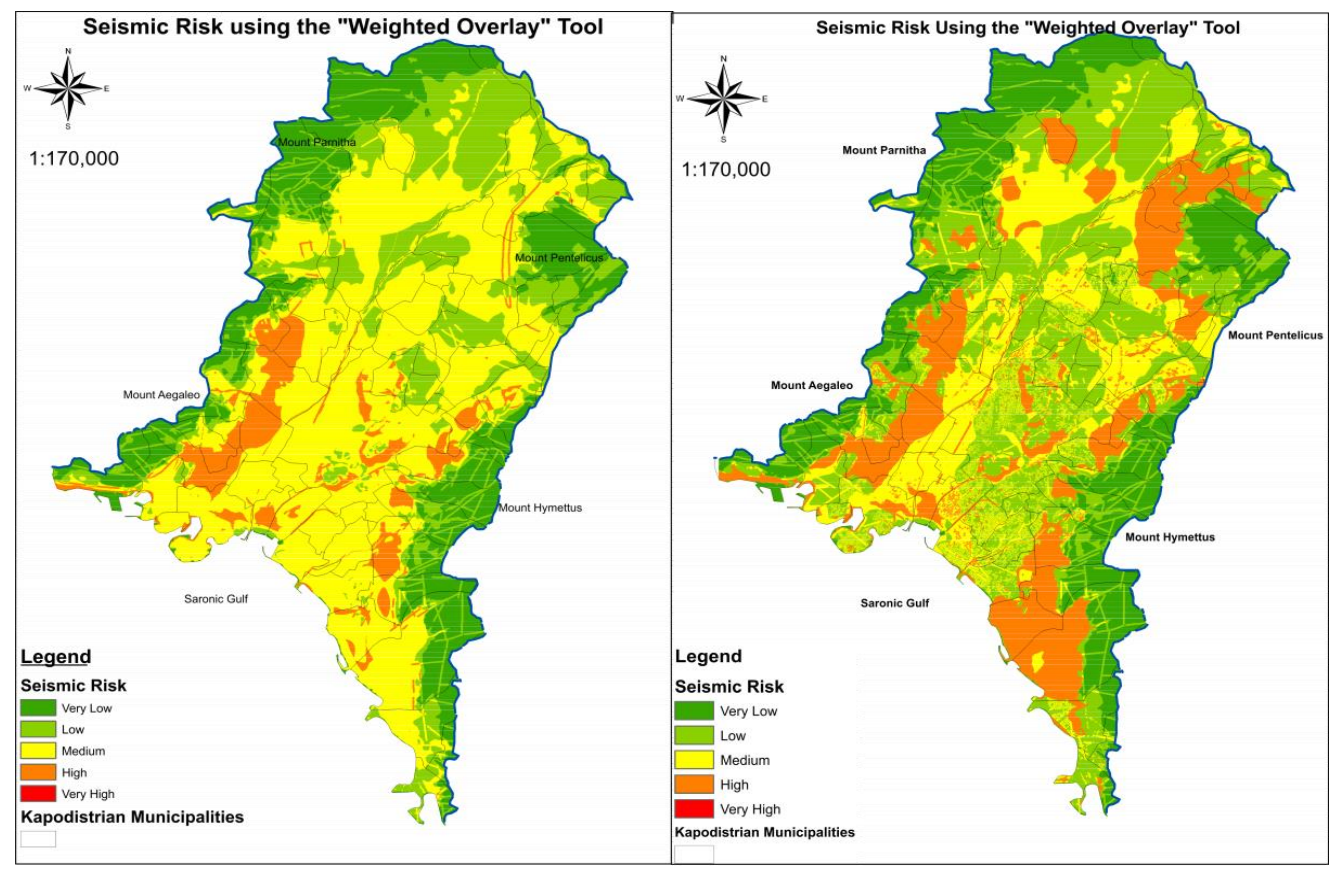

Figure 5 - Calculated "Weighted Overlay" risk maps using: the Kernel density based vulnerability map (left) and the building block based vulnerability map (right).

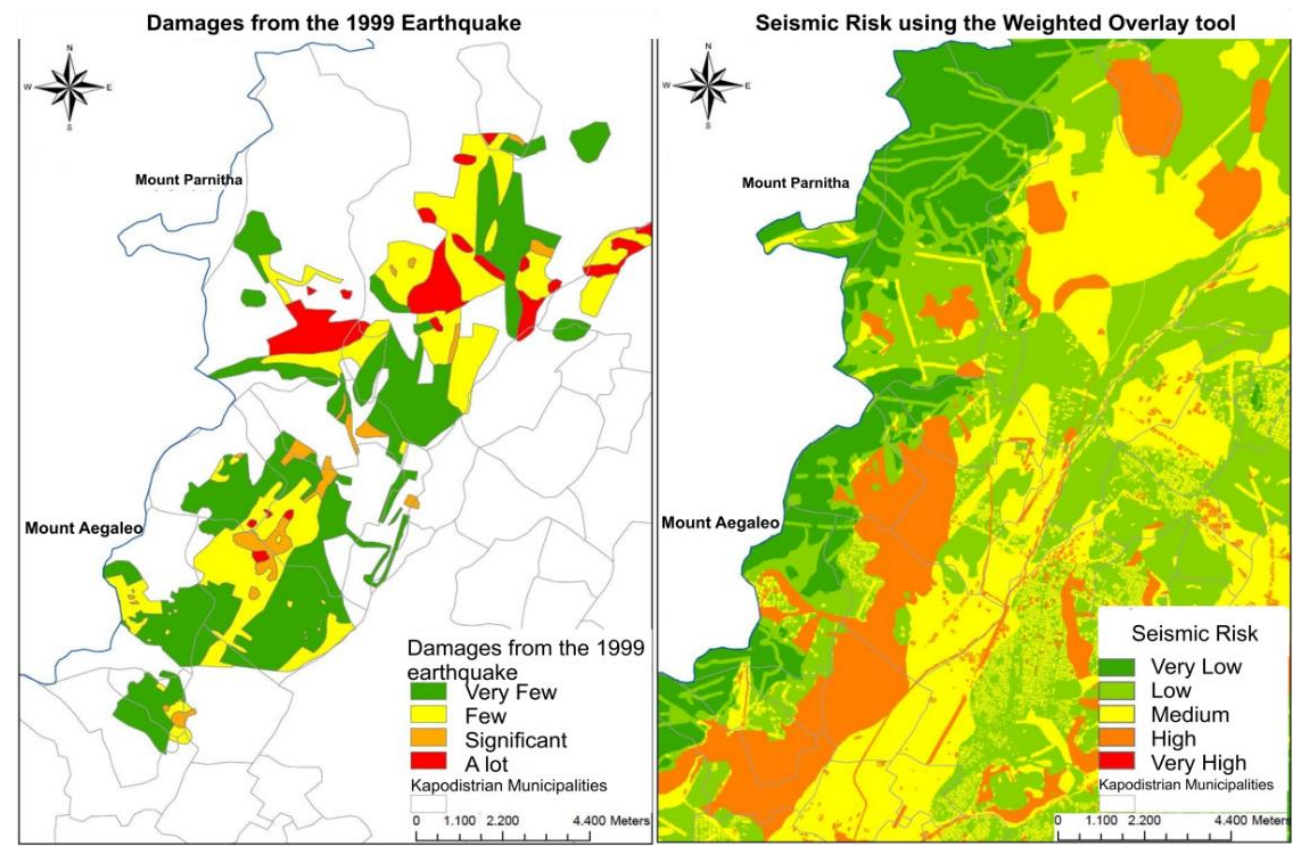

Figure 6 - Comparison between the damages from the 1999 earthquake and the calculated seismic risk. 


\section{Acknowledgments}

We would like to thank Dr Thomas Maloutas, Professor of Social Geography in the Harokopeion University for providing us with urban planning data in the Attica Basin. We would also like to thank Attiko Metro S.A. and especially Mr Dimitris Panagiotakopoulos, GIS Analyst for providing us with the building block data of the Attica Basin.

\section{References}

Alexander, D., 1993. Natural Disasters. UCL Press, London, 631, A73 pp.

Algermissen, S.T., Perkins, D., Isherwood, W., Gordon, D., Rengor, G. and Howard, C., 1975. Seismic risk evaluation of the Balkan Regions, Survey of the Seismicity of the Balkan Region, UNDP/UNESCO Report, USGS, Denver.

FEMA, 2004. Using HAZUS-MH for risk assessment, FEMA 433, Washington D.C.

Gueguen, P., Mitchel, C.L. and LeCorre, L., 2007. A simplified approach for vulnerability assessment in moderate- to-low seismic hazard regions: application to Grenoble (France), Bull. Earthq. Eng., 5, 467-490.

Jenks, G.F., 1967. The Data Model Concept in Statistical Mapping, International Yearbook of Cartography, 7, 186-190.

Karimzadeh, S., Miyajima, M., Hassanzadeh, R., Amiraslanzadeh, R. and Kamel, B., 2014. A GISbased seismic hazard, building vulnerability and human loss assessment for the earthquake scenario in Tabriz, Soil Dynamics and Earthquake Engineering, 66, 263-280.

Lantada, N., Pujades, L.G. and Barbat, A., 2003. Vulnerability and seismic damage scenarios for Barcelona (Spain) by using GIS, Geophys Res Abstr., 5, 09103.

Molina, S. and Lindholm, C.D., 2005. A logic tree extension of the capacity spectrum method developed to estimate seismic risk in Oslo, Norway, Journal of Earthquake Engineering, 9(6), 877-897.

Molina, S. and Lindholm, C.D., 2006. A capacity spectrum method based tool developed to properly include the uncertainties in the seismic risk assessment, under a logic tree scheme, ECI. Geohazards-Technical, Economical and Social Risk Evaluationl, 18-21 June 2006, Littlehommer, Norway.

Papanikolaou, D.J. and Marinos, P., 2001. Geological - Geotechnical study of Athens, EPPO Research Programme.

Papanikolaou, I.D., 2011. Uncertainty in intensity assignment and attenuation relationships: How seismic hazard maps can benefit from the implementation of the Environmental Seismic Intensity scale (ESI 2007), Quaternary International, 242, 42-51.

Petermans, T., Delveeschouwer, X., Pouriel, F. and Rosset, P., 2006. Mapping the local seismic hazard in the urban area of Brussels, Belgium, Proceedings of the 10th IAEG congress, Nottingham.

Pitilakis, K., Alexoudi, M., Argyroudis, S. and Anastasiadis, A., 2006. Seismic risk scenarios for an efficient seismic risk management: the case of Thessaloniki (Greece). In: Wasti, S.T. and Ozcebe, G., eds., Advances in earthquake engineering for urban risk reduction, Springer, New York, 229-244.

Richter, C.F., 1959. Mapping Earthquake Risk Areas, Caltech.

Sarris, A., Loupasakis, C., Soupios, P., Trigkas, V. and Vallianatos, F., 2010. Earthquake vulnerability and seismic risk assessment for urban areas in high seismic regions: an application to Chania city, Crete Island, Greece, Nat. Hazards, 54,395-412.

Toma-Danila, D., Zulfikar, C., Manea, E.F. and Cioflan, C.O., 2015. Improved seismic risk estimation for Bucharest, based on multiple hazard scenarios and analytical methods, Soil Dynamics and Earthquake Engineering, 73, 1-16. 